Science and Humanities Journal

Vol. 10, 2013, pp. 16-35 Dol: https://doi.org/10.47773/shj.1998.101.2

\title{
CONSUMER-BASED OPTIMIZATION AND PRODUCT PROFILING OF GARLIC-FLAVORED OVEN-ROASTED PEANUTS
}

\author{
Lorina A. Galvez' and Lucy B. Paloma² \\ ${ }^{1}$ Assistant Professor and ${ }^{2}$ Professor \\ Visayas State University Visca, Baybay City 6521-A \\ Leyte, Philippines
}

\begin{abstract}
An optimization study of food products is important to be able to develop a nutritious and least costly product using the most efficient processing method. In this study, optimization of an ovenroasted peanut product was done. A two-factor factorial experiment with three levels of garlic solution $(4,6 \& 8 \% \mathrm{w} / \mathrm{w})$ and roasting time $(40,45 \& 50 \mathrm{~min})$ was conducted. Consumer acceptance test and spectrum descriptive analysis were done using the 9-point Hedonic scale and $15-\mathrm{cm}$ semi-structured line, respectively.

Roasting time had significant effects on all sensory parameters studied. Garlic level significantly affected fracturability. The optimum combination of $4-8 \%(w / w)$ garlic solution and below 47 min roasting time produced a product with acceptability scores of $>6.50$. Verification study showed the predictive ability of the model which implies that the processor has confidence to choose any combination from the above-mentioned values. Product quality specifications and intensity for color, garlic aroma, hardness, crunchiness, fracturability, toothpacking, saltiness, garlic taste, bitterness taste, peanutty taste and roastedness flavor were established.
\end{abstract}

Key words: spectrum descriptive analysis, roasting time, aroma, toothpacking 


\section{IN'TRODUCTION}

Peanut (Arachis bypogea L.) is a global crop (PCRSP, 1994) since it is one of the world's principal sources of oilseed, with diverse utilization including direct consumption (Wambura et al. 2007). It can contribute to the solution of the world's food shortage, whether the need is for protein, edible oil, or calories and it is produced in more than 50 countrics in all six continents (Garcia et al, 1990a). Peanut is rich in protein and essential amino acids that prevent malnutrition (Pelto and Armar-Klemeser, 2011). It is also high in calories, minerals, antioxidants and vitamins that are essential for optimum health (Settaluri et al, 2012). It does not contain transfat but contains 85 percent unsaturated fat by content and is cholesterol-free. The fat in peanut is needed to help maintain the immune system to fight disease and infection. Unsaturated fat is a component of cell membranes, called phospholipids, needed for cell growth and daily repair of body's cells. Peanut also contains niacin, thiamine and other vitamin-B components plus essential minerals like calcium, phosphorus, potassium, magnesium, sulfur, sodium, zinc and iron (Hui, 1992). In the Philippines, about 92 percent of the total peanut production is consumed as food, 0.5 percent as seeds and 7.5 percent for non-food uses. Peanut is a significant source of resveratrol, a potential anti-aging substance which is also associated with reduced risk of cardiovascular disease and cancer (Sanders et al, 2000).

In the Philippines, most consumers prefer fried than boiled peanut or as peanut butter (Garcia et al, 1990b). In preparing fried peanuts, oil, which can be saturated or unsaturated fats, is used in frying. Saturated fats are much cheaper than the unsaturated fats. Thus in processing, higher input is needed to make quality and healthy fried peanut products. In addition, diets high in saturated fats elevate cholesterol levels (Brown, 2005) which, in worst cases, result in higher risk of cardiovascular diseases. Thus, alternative processing is needed to lessen the use of oil and reduce the cost of production. Roasting, a common practice in processing peanuts (Wambura et al. 2007), is an alternative solution. 
Roasted peanuts are resistant to rancidity and spoil less quickly due to the high monounsaturated fat content. They have a shelf life of two to three months (O'Keefe et.al, 2002). In product development, optimization study is required to produce the best product formulation which has always been the goal of food processors (Fishken, 1983 and Sidel \& Stone, 1983). Sensory evaluation can be used as a tool in developing models that identify the specific sensory attributes that are most important to product preference (Schutz, 1983).

Natural flavorings are favored nowadays because of their beneficial effects to one's health. Garlic as a natural flavoring is commonly used in oil-roasted products because it has a powerful natural antimicrobial activity against bacteria, viruses, parasites, protozoans, parasites and fungi (Jaber and Al-Mossawi,2007). Garlic sulfur compounds have vasoactive ability where the red blood cells convert garlic organic polysulfides, a known endogenous cardioprotective vascular cell signaling molecule (Benavides et. al, 2007). Thus it can reduce blood pressure (Chevalier, 1996). In addition, garlic has anticancer activity due to the antioxidant effect of the alliin in reducing the formation of carcinogenic compounds in the gastrointestinal tract (Galeone et. al, 2006). Roasting time on the other hand, is a critical factor in producing a roasted product.

It is imperative, therefore, to determine the effects of the levels of garlic and roasting time on the quality of oven-roaster peanuts, to conduct optimization study, to undertake SDA and to verify the best combinations of garlic and roasting time in processing ovenroasted peanuts. Hence, this study. 


\section{MATERIALS AND METHODS}

\section{Preparation and Product Processing}

Deshelled peanuts were sorted to remove all the defective kernels. Those having yellow color indicating possible aflatoxin contamination were removed (Haruthaithanasan, and Chompreeda. 2003). The good peanut kernels were de-skinned and then soaked in 1:1 peanut:garlic-salt solution consisting of $4 \%, 6 \%$ and $8 \%(\mathrm{w} / \mathrm{w})$ garlic to $12 \%(\mathrm{w} / \mathrm{w})$ salt solution for $10 \mathrm{~min}$ and allowed to drain for 5 min. The drained peanuts were roasted at $150+5^{\circ} \mathrm{C}$ for 40,45 and 50 min and stirred at 5 min interval. After cooling, these were packed in $0.01 \mathrm{~mm}$ thick polyethylene plastic pouches and stored at room temperature.

\section{Sensory Evaluation}

The oven-roasted peanuts were subjected to consumer acceptance test following the standard procedures described by Mabesa (1986) to assess their sensory attributes and acceptability. The products were evaluated based on aroma, texture, flavor, color and overall acceptability using the 9-point Hedonic scale. There were 54 panelists composed of employees, college students, and residents of Ormoc City, Philippines. Each panelist was given five out nine samples employing the $\mathrm{t}=9, \mathrm{k}=5, \mathrm{r}=10, \mathrm{~b}=18, \mathrm{E}=0.90$ of Cochran and Cox (1957) where $t$ refers to the number of treatments, $\mathrm{k}$ the number samples presented to panelists, $r$ the number of replications based on the plan IBD, b the number of block and $E$ the efficiency factor.

\section{Spectrum Descriptive Analysis and Sensory Profiling}

The taste panelists were all healthy peanut consumers who were not allergic to peanuts, did not have dentures/braces and did not smoke. They underwent training and a series of actual product evaluations prior to the final sensory evaluation. During the training, the panelists were provided with background knowledge on odor and taste perceptions, sensory testing methods, evaluation techniques and use of reference samples. They were trained by continuous practice or 
tasting using warm up samples with predetermined qualities. The training was done until all of the panelists came up with one decision and agreed on the terminologies and specific intensities. During the training a $15-\mathrm{cm}$ semi-structured line scale with anchors at $1.25 \mathrm{~cm}$ from each end (Meilgaard et al., 1988) was used in rating the intensity of the sensory attributes. These served as guide in the evaluation of experimental samples. Reference samples or standards were provided during the evaluation proper following standard procedure of Mabesa (1986). The panelists were given one sample at a time and indicated the intensity of each attribute by placing a vertical line on the $15-\mathrm{cm}$ semi-structured line scale that was collected after each sample. The evaluation was done twice by ten trained panelists. Quantification was accomplished by measuring the distance from the anchor points using a ruler.

\section{Experimental Design and Statistical Analyses}

The study used a 2-factor factorial experiment in randomized complete block design (RCBD) with two replicates with three levels for each factor. Data were analyzed using Statistical Analysis System (SAS, 1985) program package. Analysis of Variance (ANOVA) was used to determine significant effects of the processing variables on the sensory attributes of the product.

\section{Optimization and Modeling}

Response Surface Regression (RSREG) analysis using the statistical computer software (SAS, 1985) was used to determine the effects of garlic level and roasting time on the sensory acceptability of the product. To determine the optimum combination of roasting time and garlic level, response surface plots were made for all analyses as reference points using STATISTICA (Version 5.5). Contour plots of each parameter were superimposed to come up with the optimum region with acceptability scores of $\geq 6.50$. 


\section{Verification of optimum region}

A verification experiment was conducted using three treatments: within, near and far from the optimum region (Spiegel \& Stephens, 1999). T-test was run to determine if the observed values were significantly different from the predicted values obtained during the consumer acceptance test.

\section{RESULTS AND DISCUSSION}

\section{Sensory Evaluation}

The summary of the F-ratio of the different sensory qualities and the overall effects of the independent variables are shown in Tables 1 and 2. Statistical analyses revealed that all the sensory attributes, except texture (crunchiness), were affected significantly by the linear effect of roasting time. Significant quadratic effects of roasting time were also observed in overall acceptability, color, texture (crunchiness) and flavor acceptability. Furthermore, no significant cross product interactions were observed in all of the variables studied. Garlic level did not have significant linear and quadratic effects on all parameters studied.

Table 1. Summary of the F-ratio of the sensory qualities

\begin{tabular}{|c|c|c|c|c|c|c|}
\hline \multirow{2}{*}{$\begin{array}{l}\text { Independent } \\
\text { Variables }\end{array}$} & \multicolumn{6}{|c|}{ Sensory Oualities } \\
\hline & Overall & Color & Aroma & Texture & Taste & Flavor \\
\hline Linear & $10.969^{* * * *}$ & $59.727 * * *$ & $3.517^{*}$ & $0.562^{\mathrm{ns}}$ & 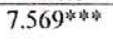 & 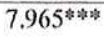 \\
\hline Quadratic & $3.656 \%$ & $3.992 * *$ & $0.331^{\mathrm{ns}}$ & $3.418^{*}$ & $1.869^{\text {ns }}$ & $3.265^{*}$ \\
\hline Cross product & $0.179^{\mathrm{ns}}$ & $1.103^{\mathrm{ns}}$ & $0.0921^{1 \mathrm{ss}}$ & $2.027^{\mathrm{ns}}$ & $0.0165^{11 s}$ & $0.706^{115}$ \\
\hline Total & $5.886^{* * *}$ & $25.708^{* * *}$ & $1.558^{\mathrm{ns}}$ & $1.998^{\mathrm{ns}}$ & $3.779^{\text {क* }}$ & $4.633^{\text {糔将 }}$ \\
\hline
\end{tabular}


Table 2. Overall effect of the independent variables on response variables

\begin{tabular}{|c|c|c|c|c|c|c|}
\hline \multirow{2}{*}{$\begin{array}{c}\text { Independent } \\
\text { Variables }\end{array}$} & \multicolumn{6}{|c|}{ Sensory Qualities } \\
\hline & Overall & Color & Aroma & Texture & Taste & Flavor \\
\hline $\begin{array}{c}\text { Amount of } \\
\text { Garlic }(\% w / w)\end{array}$ & $0.260^{15 \mathrm{~s}}$ & $0.393^{115}$ & $0.121^{\text {IIS }}$ & $1.149^{\mathrm{ns}}$ & $0.0707^{1 \mathrm{~ns}}$ & $0.285^{\mathrm{ns}}$ \\
\hline $\begin{array}{l}\text { Roasting time } \\
\text { (min.) }\end{array}$ & $9.612^{* * *}$ & $42.822^{* * *}$ & $2.506^{*}$ & $2.861^{*}$ & $6.234^{* * * *}$ & $7.654^{* * * *}$ \\
\hline
\end{tabular}

${ }^{* * *}$ Significomt at $p \leq 0.01 \quad{ }^{*}$ Significant at $p \leq 0.05$

Ns- not significant

Color Acceptability. The means of the color acceptability values ranged from 5.71-7.18 corresponding to "neither like nor dislike" to "like moderately" of the 9-point Hedonic Scale (Table 3). The response was affected mainly by roasting time (Tables 1 \&2) since the roasting process produced a dark-colored product. The level of pyrazine compounds in roasted peanuts appeared to be proportional to the extent of product browning. The higher the amount of pyrazine formed, the more brown is the product. This compound could be formed from the interaction of alpha-dicarbonyl compounds (intermediate products in the Maillard reaction) with amino acids through the Stecker degradation (Murano, 2003).

Increasing the roasting time resulted to darker (brown) peanut and consequently, color became a visual indication of the extent of roasting (Woodroof, 1973). Results further revealed that panelists "neither liked nor disliked" the color of the products roasted for $50 \mathrm{~min}$ since they were already very dark which could have resulted from advanced stage of Maillard reaction negatively affecting food color (Murano, 2003). 
Table 3. Mean consumer acceptability scores of the different roasted peanut products

\begin{tabular}{|c|c|c|c|c|c|c|c|c|}
\hline \multicolumn{3}{|c|}{ Treatments } & \multirow{2}{*}{$\begin{array}{c}\text { Overall } \\
\text { Acceptability }\end{array}$} & \multicolumn{5}{|c|}{ Sensorv Oualities } \\
\hline Trt & $x_{1}$ & $\mathbf{X}_{2}$ & & Color & Aroma & Texture & Taste & Flavor \\
\hline 1 & 4.0 & 40 & 6.97 & 6.99 & 6.74 & 6.79 & 6.83 & 6.86 \\
\hline 2 & 4.0 & 45 & 6.84 & 6.88 & 6.59 & 6.95 & 6.90 & 6.94 \\
\hline 3 & 4.0 & 50 & 6.24 & 5.84 & 6.3 & 6.7 & 6.14 & 6.29 \\
\hline 4 & 6.0 & 40 & 6.69 & 7.18 & 6.51 & 6.48 & 6.6 & 6.66 \\
\hline 5 & 6.0 & 45 & 6.84 & 6.59 & 6.55 & 6.99 & 6.66 & 6.81 \\
\hline 6 & 6.0 & 50 & 6.4 & 5.84 & 6.63 & 6.87 & 6.54 & 6.65 \\
\hline 7 & 8.0 & 40 & 6.95 & 7.16 & 6.8 & 7.09 & 6.98 & 7.06 \\
\hline 8 & 8.0 & 45 & 6.86 & 6.74 & 6.69 & 7.1 & 6.71 & 6.86 \\
\hline 9 & 8.0 & 50 & 6.34 & 5.71 & 6.28 & 6.56 & 6.25 & 6.25 \\
\hline
\end{tabular}

Aroma Acceptability. Aroma acceptability scores ranged from 6.28-6.8, or "like slightly" to "like moderately" in the 9-point Hedonic Scale (Table 3) and was significantly affected by roasting time (Table 2). Woodroof (1973) observed that heat processing or roasting itself greatly improved the aroma of roasted peanuts. The garlic levels did not significantly affect aroma acceptability which could be due to the low levels of garlic used in the study. Generally, acceptability ratings lowered significantly when roasting time was extended to $50 \mathrm{~min}$. At this stage, a burnt aroma was developed due to a much extended Maillard reaction.

Texture (Crunchiness) Acceptability. Crunchiness acceptability scores ranged from 6.48-7.1 or "like slightly" to "like very much" in the 9-point Hedonic Scale (Table 3) which imply that the product produces an acceptable sound when eaten. It was also found that roasting time significantly affected texture (crunchiness) acceptability (Table 2). Texture acceptability values were highest at the midlevel roasting time which was $45 \mathrm{~min}$. When extended to $50 \mathrm{~min}$, a negative effect on texture was observed. Murano (2003) mentioned that food water activity can be viewed as a predictor of food texture. Roasted peanuts belong to the hard and crisp (lowest Aw) category. $\mathrm{He}$ further said that hard texture is associated with bound water and relatively low moisture and Aw levels, and that food fat and moisture content also play a role in texture measurement and perception (Murano, 2003). 
Taste Acceptability. Taste acceptability scores had a mean of 6.38-7:05 or "like slightly" to "like moderately" (Table 3). Significant effect of roasting time on taste acceptability was observed (Tables 1 and 2). Garlic level had no significant effect on taste which may be due to the low levels of garlic used.

Generally, acceptability increased to the midlevel roasting time which could mean that the taste of peanut plus the roasted flavor were more dominant in the midlevel roasting time. Further heating produced a burnt product resulting to bitter taste which negatively affected its taste acceptability.

Flavor Acceptability. Flavor which is mainly composed of taste and odor or aroma (Deman, 1980) is the overall integrated perception of all the contributing senses (Fennema, 1996). In this experiment, flavor acceptability scores were affected significantly by roasting time (Tables 1 and 2). Roasting time had a strong influence on taste and aroma which coincided with the results of aroma and taste acceptability. Maillard reaction produced a pyrazine compound which gave a pleasant product aroma and odor (Murano, 2003). Alkyl pyridines (products from browning reactions) contribute to the flavors of all roasted, toasted or similarly thermally processed foods (Fennema, 1996). Furthermore, heating or roasting enhances the flavor of the products (Woodroof, 1973). Fennema (1996) mentioned that browning reactions are almost always involved in the development of process flavors in foods. They contribute to generally nutty, meaty, roasted, toasted, burnt, or caramel odors. The obtained acceptability scores were very high ranging from 6.51 to 7.28 (Table 3) which mean that the products were like slightly to like moderately by the panelists.

Overall Acceptability. Overall acceptability serves as the reference parameter or the overall perception of the product by the consumer panel. Overall acceptability rating was 6.04 to 7.21 which fall under "like slightly" to "like moderately" in the 9 - point Hedonic scale (Table 3). 
Roasting time caused significant differences on the overall acceptability of the products (Table 1). Garlic level had no significant effect which could be due to the low levels of garlic used.

Roasting time affected all the parameters because it significantly changed the color, aroma, texture (crunchiness), taste and flavor of the products (Table 2). It can be noted that the least overall acceptability was observed in products subjected to 50 min roasting time with all of the garlic levels used (Fig. 1).

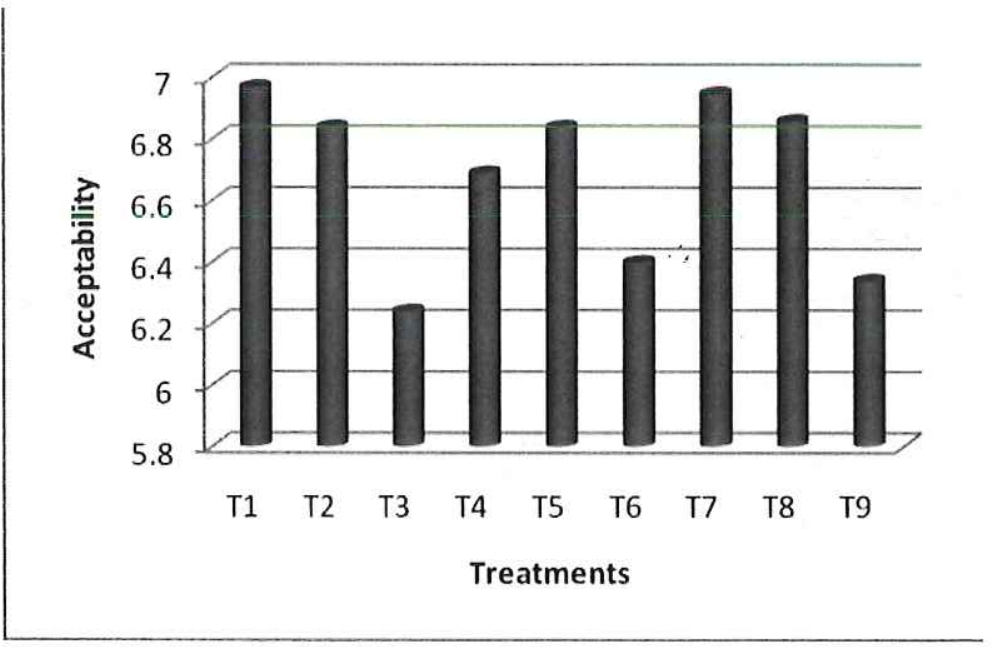

Figure 1. Overall acceptability of the nine treatments

\section{Attainment of the optimum processing conditions}

Superimposed contour plots of the interaction between garlic concentration and roasting time in each sensory attribute are shown in Figure 2. The optimum combinations were determined by setting a 6.5 acceptability score or higher using the 9-point Hedonic Scale. The shaded region represents the optimum combinations of garlic and roasting time. Color acceptability values seemed to be the limiting factor during the optimization study. Moreover, it can be observed that 
more than half of the contour map going to the top was occupied by the optimum region. This means that any level of roasting time below 47 minutes combined with any level of garlic from $4-8 \%$ (w/w) could produce an optimum product with $>6.50$ acceptability scores (like slightly to like moderately) in 9-point Hedonic Scale. This result gives the processors the option to choose a set of optimum combinations of roasting time and garlic level in order to produce the best product.

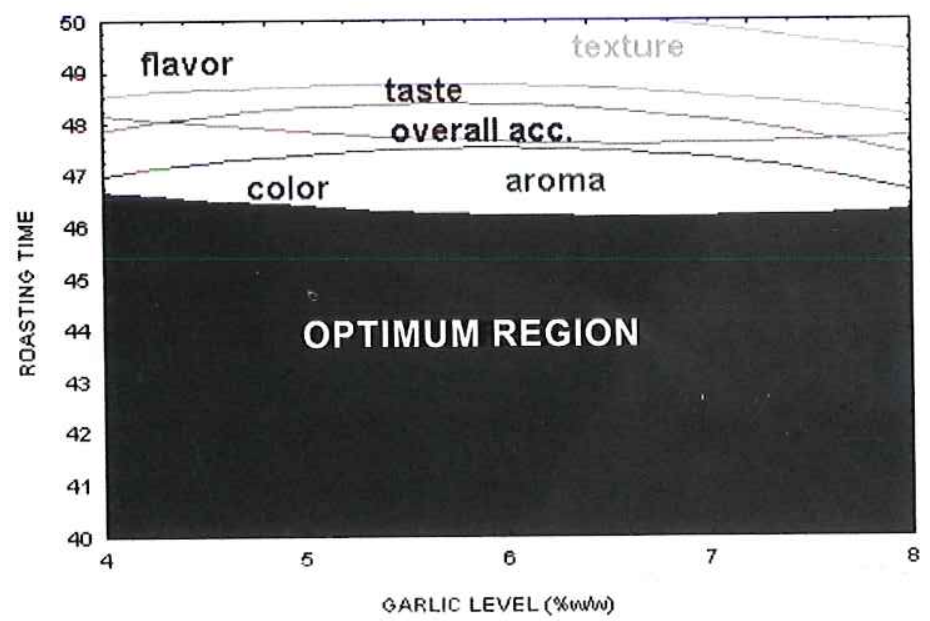

Figure 2. Shaded region represents the optimum region between the roasting time in minutes and garlic level $(\% \mathrm{w} / \mathrm{w})$.

\section{Verification of the optimum processing conditions}

Six treatments were found in the optimum region, but only $\mathrm{T} 7$ $(8 \% \mathrm{w} / \mathrm{w}$ garlic and $40 \mathrm{~min}$ roasting time) was chosen for the verification study. This was because of its higher acceptance in all sensory qualities. A comparison between observed and predicted values for the sensory attributes of the three treatments tested is presented in Table 4 . The $\mathrm{t}$-calculated values were determined following the procedure adopted by Palomar et al. (1994) and 
these values were compared with the standard values in Spiegel and Stephens (1999). The study revealed a non-significant result in all parameters which indicates the predictive ability of the models used in the optimization study. Thus, food processors have the confidence to choose any combination from the optimum region and are assured of a product acceptability score of $>6.50$ in the 9-point Hedonic Scale.

Table 4. Predicted and observed values in the verification study

\begin{tabular}{llllllllll}
\hline & \multicolumn{3}{c}{$\mathbf{X}_{\mathbf{1}}$} & \multicolumn{3}{c}{$\mathbf{X}_{\mathbf{2}}$} & \multicolumn{3}{c}{$\mathbf{X}_{\mathbf{3}}$} \\
\cline { 2 - 9 } Aroma & 6.91 & 6.72 & $0.17^{\text {ns }}$ & 6.39 & 6.62 & $0.15^{\text {ns }}$ & 6.84 & 6.17 & $0.41^{\text {ns }}$ \\
\cline { 2 - 9 } Texture & 7.21 & 6.98 & $0.20^{\text {ns }}$ & 6.74 & 6.82 & $0.05^{\text {ns }}$ & 7.17 & 6.92 & $0.19^{\text {ns }}$ \\
Taste & 6.99 & 6.62 & $0.29^{\text {ns }}$ & 6.43 & 6.75 & $0.18^{\text {ns }}$ & 6.84 & 6.60 & $0.16^{\text {ns }}$ \\
Flavor & 6.99 & 6.83 & $0.15^{\text {ns }}$ & 6.54 & 6.65 & $0.07^{\text {ns }}$ & 6.97 & 6.78 & $0.16^{\text {ns }}$ \\
Color & 6.76 & 6.35 & $0.31^{\text {ns }}$ & 5.74 & 7.20 & $1.17^{\text {ns }}$ & 7.02 & 6.08 & $0.59^{\text {ns }}$ \\
Overall & 6.89 & 6.83 & $0.05^{\text {ns }}$ & 6.08 & 6.93 & $0.57^{\text {ns }}$ & 7.10 & 6.65 & $0.29^{\text {ns }}$ \\
\hline
\end{tabular}

9- pt Hedonic Scale (1-dislike extremely to 9-like extremely)

$X_{1}-R T=50 \mathrm{~min}$ and $G C=6 \%(w / w) ; X_{2}-R T=40 \mathrm{~min}$ and $G C=8 \%(\mathrm{w} / \mathrm{w})$

$X_{3}-R T=48 \mathrm{~min}$ and $G C=5 \%(w / w) ; N s-n o t$ significant at $5 \%$ level of significance

T-tab-1.67; where RT=Roasting Time and GC= Garlic Concentration

\section{Spectrum descriptive analysis and sensory profiling}

A commercial garlic-flavored roasted peanut product ("Happy" brand) served as reference and standard sample during the product evaluation using a $15-\mathrm{cm}$ semi-structured line scale. This reference sample possessed the following descriptions and intensities: color $=7.0$, aroma (garlic) $=6.0$, texture (hardness $)=7.0$, texture (crunchiness) $=7.0$, texture (fracturability $)=7.0$, tooth packing $=5.0$, taste (saltiness) $=7.0$, taste (bitterness) $=1.0$, flavor (garlic) $=6.0$, flavor (peanutty) $=1.0$, and flavor (roastedness) $=7.0$ as observed and agreed by the trained panelists.

Table 5 shows the descriptive values of the nine treatments. Range of intensities was determined to at least get the product specifications. The color (6.65-8.10) was lighter to a little bit darker than the reference sample. The garlic aroma had an intensity of 4.485.11 which was lower than the reference sample. The product was harder (5.78-6.21) than the "Eden" cheese brand but softer than the reference sample. Crunchiness was 5.52-6.22 which was less than that of the reference sample. In terms of fracturability (5.63-6.07), it was 
more brittle than "Graham" brand crackers but less brittle than the reference sample. The tooth packing (5.22-5.58) of the sample was slightly higher than that of the reference sample and less than that of "Graham" crackers. The saltiness (3.99-4.96) was very low compared to the reference sample. The bitterness (1.0-1.70) was little bit higher but the garlic taste (3.73-4.58) was lower than that of the reference sample. It also had a more peanutty taste $(1.10-1.58)$ than the reference sample. The roastedness flavor (6.37-7.75) was slightly lower to a little bit higher that of the reference sample.

Correlation study of the consumer acceptability and trained panel data

Correlation analysis revealed that color and roastedness scores were highly correlated with color, saltiness, flavor and overall acceptability (Table 6). However, negative correlations were observed, meaning that as the intensities of the color or roastedness increased (trained panel), the overall, color, saltiness and flavor acceptability decreased (consumer panel). The sign of the coefficient indicates the direction of the relationship, and its absolute value indicates strength, with larger absolute values indicate stronger relationship (Mason, et al., 1989). 
Table 5. Means of the spectrum descriptive analysis data using using the $15-\mathrm{cm}$ semi-structured line.

\begin{tabular}{|c|c|c|c|c|c|c|c|c|c|c|}
\hline \multirow[b]{2}{*}{ Sensory Qualities } & \multicolumn{9}{|c|}{ Treatments } & \multirow{2}{*}{$\begin{array}{c}\text { Reference } \\
\text { sample }\end{array}$} \\
\hline & $\mathrm{T}_{1}$ & $\mathbf{T}_{2}$ & $\mathbf{T}_{3}$ & $\mathbf{T}_{4}$ & $\mathrm{~T}_{5}$ & $\mathrm{~T}_{6}$ & $\mathbf{T}_{7}$ & $\mathbf{T}_{8}$ & $T_{9}$ & \\
\hline Color & 6.73 & 7.59 & 8.51 & 6.65 & 8.10 & 8.99 & 7.0 & 7.82 & 8.91 & 7.0 \\
\hline Aroma Garlic & 4.54 & 4.91 & 4.63 & 4.59 & 5.11 & 4.77 & 4.48 & 4.86 & 5.39 & 6.0 \\
\hline Hardness & 5.96 & 6.13 & 5.74 & 5.94 & 5.78 & 5.86 & 6.10 & 6.21 & 6.49 & 7.0 \\
\hline Crunchiness & 5.59 & 6.20 & 5.78 & 5.52 & 5.78 & 5.94 & 5.94 & 6.22 & 6.32 & 7.0 \\
\hline Fracturability & 5.66 & 5.75 & 5.83 & 5.63 & 5.64 & 5.79 & 5.96 & 6.07 & 6.15 & 7.0 \\
\hline Tooth packing & 5.52 & 5.22 & 5.61 & 5.45 & 5.53 & 5.11 & 5.58 & 5.45 & 5.21 & 5.0 \\
\hline Taste/Saltiness & 4.83 & 4.69 & 4.84 & 4.96 & 3.99 & 4.56 & 4.62 & 4.88 & 4.92 & 7.0 \\
\hline Bitterness & 1.14 & 1.37 & 1.12 & 1.0 & 1.7 & 1.47 & 1.04 & 1.46 & 1.51 & 1.0 \\
\hline Garlic & 4.05 & 4.58 & 4.09 & 3.99 & 4.16 & 3,98 & 3.73 & 4.34 & 4.39 & 6.0 \\
\hline Peanutty & 1.58 & 1.37 & 1.16 & 1.55 & 1.14 & 1.27 & 1.10 & 1.14 & 1.13 & 1.0 \\
\hline Flavor/Roastedness & 6.37 & 7.51 & 8.01 & 6.48 & 7.75 & 8.67 & 6.84 & 7.59 & 8.39 & 7.0 \\
\hline
\end{tabular}

Note: Reference sample- Happy oil roasted peamus with garlic, $n=10 ; T_{1}-4 \%$ garlic: 40 min roasting time: $T_{r} 4 \%$ garlic: 45 min roasting time $: T_{3}-4 \%$ garlic: 50 min roasting time; $T_{4}-6 \%$ garlic: 40 min roasting fine; $T_{5}-6 \%$ garlic: 45 min masting time; $T_{6}-6 \%$ garlic: 50 min roasting time; $T_{7}-8 \%$ garlic: 40 min roasting timte; $T_{8}-8 \%$ garlic: $45 \mathrm{~min}$ roasting time: $T_{0}-8 \%$ garlic: 50 min roasting fine

Descriptors: Color: 0-white paper, 5-brown sugar, 7-Happy roasted peamut, 15-Kinugay sugar; Garlic aroma: 6Happy roasfed peamut: Hardness: 4.5-Eden cheese, 7-happy roasted peamu, 14.75-Fox's candy; Chunchiness: 7 . Happy roasted peanut; Fracturability: 4.2-Graham crachers, 5-Raisin cookies, 7-Happy roasied peamut, 14-Fox's candy: Toolh packing: 5- Happy roasted peamu, 7.5-Graham crackers, 9-Eden cheese, 15-Fox's candy: Saltiness: 2.5-Sally 2.5. 5-Salty 5. 7-Hoppy roasted peanu, 8.5-Salty 8.5; Bitlerness: 1-Hoppy roasted peamut, 2.5-Biller 2.5, 5-Bitter 5, 10-Bifter 10; Gantic taste: 1-Happy roasted peamu; Peamuty taste: 1-Happy roasted peanut: and Roastedness flavor: 7-Happy roasted peanut

Table 6. Correlation analysis of the SDA and consumer acceptability data.

\begin{tabular}{lcccccc}
\hline \multicolumn{1}{c}{$\begin{array}{c}\text { Sensory } \\
\text { Qualities }\end{array}$} & Overall & Color & Aroma & Crunchiness & Saltiness & Flavor \\
\cline { 2 - 7 } Color & $-.576^{*}$ & $-.854^{* *}$ & -.419 & -.140 & $-.568^{*}$ & $-.496^{*}$ \\
Aroma Garlic & -.245 & -.376 & -.331 & -.281 & -.066 & -.212 \\
Hardness & .007 & .064 & -.069 & -.261 & -.032 & .027 \\
Crunchiness & -.142 & -.181 & -.023 & -.018 & -.018 & -.040 \\
Fracturability & -.221 & -.284 & -.183 & -.184 & -.017 & -.184 \\
Toothpick & .039 & .165 & -.054 & -.013 & -.001 & -.034 \\
Saltiness & .004 & .109 & -.068 & -.039 & .031 & .048 \\
Bitterness & -.041 & -.386 & .052 & .331 & -.014 & .040 \\
Garlic taste & -.111 & -.262 & -.103 & -.067 & .076 & -.053 \\
Peanut taste & .041 & .279 & .218 & -.082 & .208 & .039 \\
Roastedness & $-.609^{* *}$ & $-.829^{* *}$ & -.445 & -.087 & $-.005^{* *}$ & $-.530^{*}$ \\
\hline
\end{tabular}

*Correlation is significant at the 0.05 level (2-tailed)

*s Correlation is siguificant at the 0.01 level (2-tailed) 
In addition, regression analyses of the spectrum descriptive data show that garlic level significantly affected fracturability at $5 \%$ level of significance. On the other hand, roasting time affected significantly color and roastedness (1\%). Fracturability showed an R2 of $29.8 \%$ while color and roastedness variations were found to have an R2 of $76.1 \%$ and $75 \%$ R2, respectively, (Table 7).

Table 7. Regression analysis of the intensity scaling of the sensory qualities as evaluated by the trained panelist as affected by garlic concentration and roasting time.

\begin{tabular}{lccc}
\hline \multicolumn{1}{c}{ Sensory Qualities } & $\begin{array}{c}\text { Amount of Garlic } \\
(\mathbf{w} / \mathbf{w} \%)\end{array}$ & $\begin{array}{c}\text { Roasting Time } \\
(\mathbf{m i n})\end{array}$ & $\mathbf{R}^{2}$ \\
\hline Color & $0.308^{\mathrm{ns}}$ & $0.000^{* *}$ & 0.761 \\
Garlic Aroma & $0.456^{\mathrm{ns}}$ & $0.195^{\mathrm{ns}}$ & 0.139 \\
Hardness & $0.111^{\mathrm{ns}}$ & $0.911^{\mathrm{ns}}$ & 0.161 \\
Crunchiness & $0.168^{\mathrm{ns}}$ & $0.143^{\mathrm{ns}}$ & 0.230 \\
Frácturability & $0.043^{*}$ & $0.244^{\mathrm{ns}}$ & 0.298 \\
Tooth packing & $0.747^{\mathrm{ns}}$ & $0.174^{\mathrm{ns}}$ & 0.125 \\
Saltiness & $0.963^{\mathrm{ns}}$ & $0.854^{\mathrm{ns}}$ & 0.002 \\
Bitterness & $0.397^{\mathrm{ns}}$ & $0.071^{\mathrm{ns}}$ & 0.232 \\
Gárlic taste & $0.747^{\mathrm{ns}}$ & $0.465^{\mathrm{ns}}$ & 0.043 \\
Pdanut taste & $0.107^{\mathrm{ns}}$ & $0.115^{\mathrm{ns}}$ & 0.277 \\
Roastedness & $0.244^{\mathrm{ns}}$ & $0.000^{* *}$ & 0.751 \\
\hline
\end{tabular}

** correlation is significant at the 1\% level (2-tailed); * correlation is significant at the $5 \%$ level (2-tailed)

\section{CONCLUSION}

Roasting time significantly affected color, aroma, taste, flavor and overall acceptability of the oven-roasted peanut products. In addition, SDA revealed also a significant effect of roasting time on color and roastedness which means roasting time plays a great role on the acceptability of the product. The level of garlic on the other hand, did not affect the product acceptability which was probably caused by the very low levels of garlic used. However in the descriptive analysis, garlic level caused a significant effect on the fracturability of the product. The optimum product with an acceptance score of $>6.50$ in the 9-point Hedonic Scale can be prepared by flavoring the peanuts with garlic solution of $4-8 \% \mathrm{w} / \mathrm{w}$ and roasted in less than 47 minutes. 
The color acceptability was found to be the limiting factor in the study. Verification study revealed non-significant results in all of the sensory parameters studied which implies the predictive ability of the models. Thus, the processor has the confidence to choose any combinations from the optimum region and that the product has an acceptability score of $>6.50$ using the 9-point Hedonic Scale.

The product profile was established for $\mathrm{T} 7(8 \% \mathrm{w} / \mathrm{w}$ garlic and 40 min roasting time) as follows: color (7.0), garlic aroma (4.48), hardness (6.10), crunchiness (5.94), fracturability (5.96), toothpacking (5.58), saltiness (4.62), bitterness (1.04), garlic taste (3.73), peanut taste (1.10) and roastedness flavor (6.84) using 15 -cm semi-structured line.

\section{ACKNOWLEDGMENT}

The authors would like to thank Dr. Lutgarda S. Palomar, Project Leader, Mr. Jonathan L. Oclarit for the support in realizing this paper, and PCRSP-USAID for the financial support of the project. 


\section{LITERATURE CITED}

BENAVIDES, GA, SQUANDRITO, GL, MILLS, RW, PATEL, HD, ISBELL,TS, PATEL, RP, DARLEY-USMAR, VM, DOELLER, JE, KRAUS, DW. 2007. Hydrogen sulfide mediates the vasoactivity of garlic. PNAS 104:17977-17982.

BROWN, J. E. 2005. Nutrition Now. 4th edition. Wadsworth Thomson Learning. United States. pp. I-15.

COCHRAN, W.G. and G.M. COX. 1957. Experimental Designs. 2nd Edition. John Wiley Sons, Inc., New York. pp. 439-482.

CHEVALIER, A. 1996. The Encyclopedia of Medicinal Plants. DK Publishing, London. pp. 1872-1882.

DEMAN, J.M. 1980. Principles of Food Chemistry, The AVI Publishing Company Inc., Westport, Connecticut, USA, p. 189, 227.

FENNEMA, O.R. 1996. Food Chemistry. 3rd Edition. Marcel Dekker, Inc. New York. 1067 pp.

FISHKEN, D. 1983. Consumer-oriented product optimization. Food Tech. 37 (11): 49-52.

GALEONE,C.,PELUCCHINI,C.,LEVI,F.,NEGRIE.,FRANCESC HI, S.,TALAMINI,R.,GIACOSA,A.,La VECCHIA,C. 2006. Onion and garlic use and human cancer. Am. J. Clin. Nutr. 84(5):1027-1032

GALVEZ, F.C.F., LUSTRE, A.O., RESURRECCION, A.V.A. and PALOMAR, L.S. 2002. Control of aflatoxin in raw peanuts through proper manual sorting. Monograph Series No.3. United States Agency for International Development-Peanut Collaborative Research Support Program (P-CRSP). Project 04.(USA and Philippines). 
GARCIA,V.V., S.M. RUBICO, R.C. ARENAS, and R.D. VALMONTE, 1990a. Peanut consumption patterns in the Philippines, PCARRD, Book Series No. 90/1990, Los Banos, Laguna. P.10

GARCIA,V.V., S.M. RUBICO, R.C. ARENAS, and R.D. VALMONTE, 1990b. Peanut consumption patterns in the Philippines, PCARRD, Book Series No. 91/1990, Los Banos, Laguna.

HARUTHAITHANASAN, V. and P. CHOMPREEDA. 2003. Processing of Peanut Products. In: Manual on International Training Program on Technology Transfer, Storage Handling, Processing, and Quality Measurement of Peanuts and Peanuts Products. Sept. 29-Oct. 7, 2003. Bangkok, Thailand

HUI, Y.H. 1992. Encyclopedia of Food Science and Technology. Vol.3 Wiley Inter-Science Publication. John Wiley and Sons Inc. New York. 2038p.

JABER, MA and Al-MOSSAWI A. 2007. Susceptibility of some multiple resistant bacteria to garlic extracts. Afr. J. Biotechnol. 6(6):771-776

MABESA, L.B., 1986. Sensory evaluation of foods. Principles and Methods. College of Agriculture, UPLB, Laguna 119p.

MASON,R.L., R.F. GUNST, AND J.L. HESS. 1989. Statistical Design and Analysis of Experiments with Applications to Engineering and Science. John Wiley \& Sons,N.Y., 692 pp.

MEILGAARD, M., CIVILLE, G.V. AND CARR, B.T.1993.Sensory evaluation Techniques, 2nd ed. CRC Press, Boca Raton, Florida.

MURANO, P.S. 2003. Understanding Food Science and Technology. Thomson Wadsworth, Canada. 449 pp. 
O'KEEFE,S.F., B.C.A. FORTT and R.W. MOZINGO. 2002. Shelf life of roasted inshell high oleic and normal oleic Virginia-type peanuts. Abstract. No.46C-18.Presented at the 2002 IFT Annual Meeting and Food Expo, Anaheim,Cal.

PALOMAR, L.S., F.C.F.GALVEZ, A.V.A. RESURRECCION and L. R. BEUCHAT. 1994. Optimization of a Peanut-Sweet Potato Cookie Formulation. Lebensmittel-Wissenschaftund-Technologie, 27, pp. 314-318.

PEANUT COLLABORATIVE RESEARCH SUPPORT PROGRAM, 1994. Improving the Global Production and Use of Peanut for Economic Growth, Human and Nutrition, and Environmental Sustainability. US Agency for International De velopment Grant, p. 6

PELTO, G.H. AND M. ARMAR- KLEMESER. 2011. "Balancing Nurturance, Cost and Time: Complementary feeding in Accra, Ghana', Maternal and Child Nutrition.Vol.7,No.3 pp66-81

SANDERS, T.H., McMICHAEL Jr, R.W., HENDRIX, K.W. 2000. "Occurrence of resveratrol in edible peanuts". Journal of Agricultural and Food Chemistry 48 (4): 1243-1246.

SAS, 1985. SAS User's Guide: Statistical Version.5.5. SAS Institute, Inc. Cary, Inc.

SCHUTZ, H.G. 1983. Multiple regression approach to optimization. Food Tech 11(9):48-62.

SETTALURI, N.S., C.V.K. KANDALA, N. PUPPALA, J.SUNDARAM. 2012.Peanuts and their nutritional aspects: a review. Food and Nutrition Sciences,Vol 3, pp1644-1650

SIDEL, J.L. and H. STONE. 1983. An introduction to optimization research. Food Tech 11(9):9-14. 
SPIEGEL, M.R. and J. STEPHENS. 1999. Schaum's Outline of "Theory \& Problems of Statistics" 3rd edition. McGraw-Hill, New York. 538 pp.

WANBURA, P., W.YANG, L.WILLIAMS, H.FENG AND T.M. RABABAH. 2007. Shelf life extension of roasted peanuts by surface lipid removal. American Society of Agricultural and Biological Engineers. Vol 50(4):1315-1321.

WOODROOF, J.G. 1973. Peanuts: Production, Processing, Products, 2nd ed. AVI Publishing Company, Inc., Westport, Connecticut. $327 \mathrm{pp}$. 